\title{
IMAGENS DE METSA
}

Inin Metsa

Inin Metsa é pintor, etnia Shipibo do rio Ucayali no Peru. Em 2013, participou da Mira! Artes Visuais Contemporâneas dos Povos Indígenas no Centro Cultural da UFMG. 


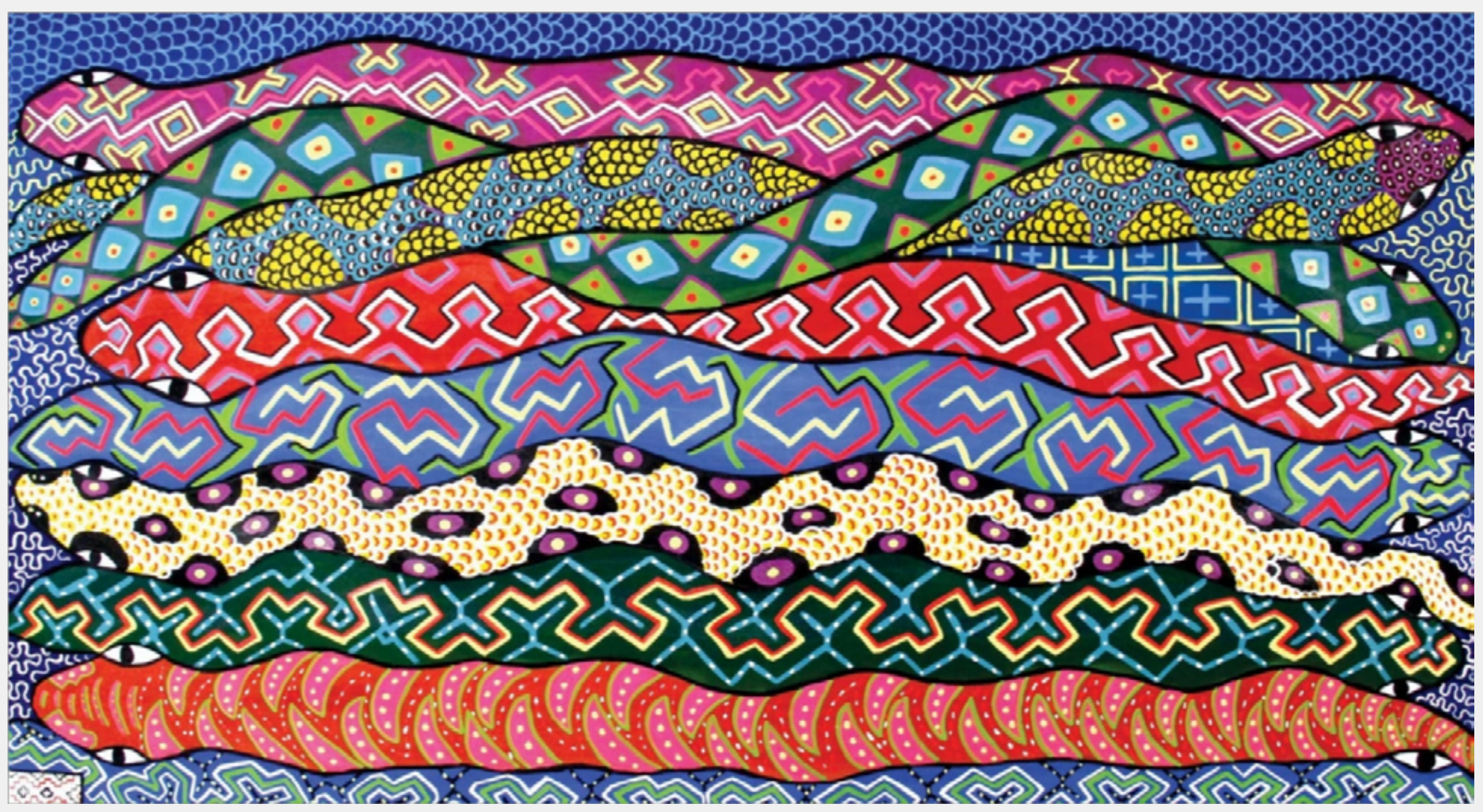




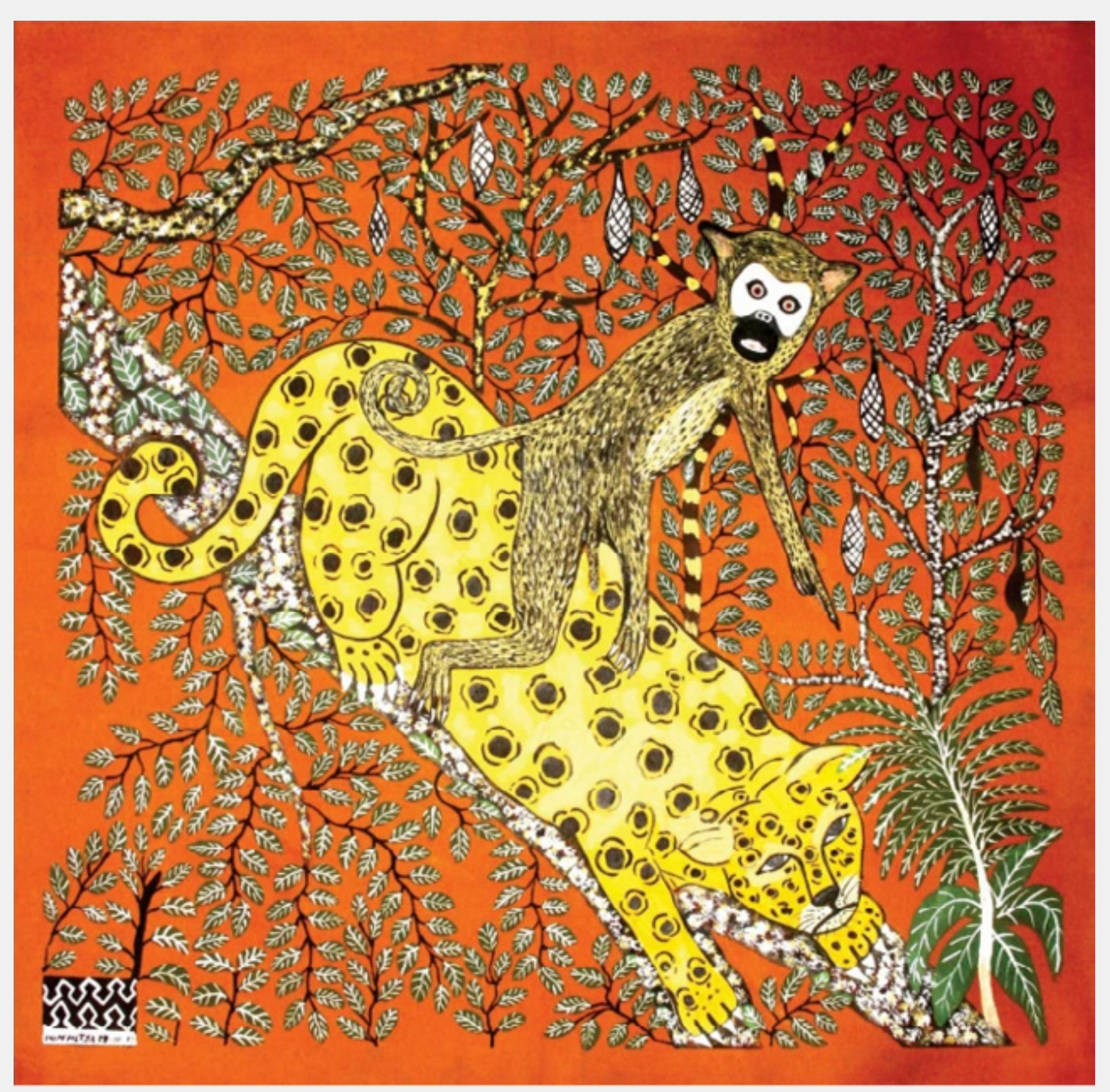

